REVIEW ARTICLE

\title{
Sepsis Mimics
}

\author{
Santosh T Soans ${ }^{1}$, Sahana Panambur ${ }^{2}$
}

\begin{abstract}
Mimics of sepsis are a common cause of misdiagnosis in the emergency department. Studies have shown that more than $50 \%$ of patients identified and treated for severe sepsis have negative culture results. Of the patients identified with a sepsis syndrome at presentation, $18 \%$ have a noninfectious disease that mimics sepsis. Hence, it is important to differentiate sepsis from several noninfectious diseases that may closely mimic sepsis. Conditions such as diabetic ketoacidosis (DKA), Kawasaki disease (KD) shock syndrome, pancreatitis, and inborn errors of metabolism (IEM) mimic the clinical presentation of sepsis, while anaphylaxis, adrenal insufficiency, hemorrhage, pulmonary embolism, and spinal cord injury mimic the hemodynamic parameters of sepsis. Due to a significant overlap in the clinical, hemodynamic, as well as laboratory parameters, sepsis and its mimics are often not distinguishable on the initial assessment. Unresolving sepsis with appropriate fluid resuscitation and antimicrobials may be a clue that it is not sepsis alone. High index of suspicion combined with a systematic approach and prompt therapy is important as many can be progressive and fatal. Nonetheless, sepsis is still the commonest. Beware mimics are there but rare!!
\end{abstract}

Keywords: Diabetic ketoacidosis, Inborn errors of metabolism, Kawasaki, Macrophage activation syndrome, Sepsis mimic.

Pediatric Infectious Disease (2019): 10.5005/jp-journals-10081-1217

\section{INTRODUCTION}

Quite commonly we reflexly label any ill-appearing patient with an elevated body temperature and an associated tachycardia as having sepsis. If in a seemingly septic patient no obvious source of infection is identified or if the patient is not improving with antimicrobials and fluids, it is important to broaden the differential diagnosis to conditions that can mimic its presentation.

In the emergency department, mimics of sepsis are a common cause of misdiagnosis. It has been observed that more than $50 \%$ of patients identified and treated for severe sepsis have negative culture results. Of the patients identified with a sepsis syndrome at presentation, $18 \%$ have a noninfectious disease that mimics sepsis (Table 1). ${ }^{1}$

\section{Diabetic Ketoacidosis}

Despite improvements in diabetic care, diabetic ketoacidosis (DKA) remains a significant clinical problem and a life-threatening complication. It is a complex disordered metabolic state characterized by ketosis, acidosis, and hyperglycemia. Clinical presentation of DKA with hypotension, altered sensorium, abdominal pain, and an infective focus can be confused with septic shock. Evaluate for cause of DKA such as infection, trauma, noncompliance, and pancreatitis. Obtain baseline electrocardiogram, metabolic profile, chest radiograph, urinalysis, lipase, and thyroid stimulating hormone. Insulin is administered along with fluid resuscitation and electrolyte management, especially potassium. ${ }^{2}$

\section{Kawasaki Disease}

Kawasaki disease (KD) is an acute febrile multisystem vasculitis with varied presentations. Clinical features are usually transient, and all may not be seen at a single time. This requires high index of suspicion as no investigations are diagnostic in the acute phase. Classical coronary artery aneurysm that occurs in KD may not be seen in the initial echocardiogram done within the first week. The presence of thrombocytosis with sterile cultures and poor response to antibiotics is an important clue. Intravenous immunoglobulin is the standard of care and should be given within 10 days of illness for best efficacy.

\footnotetext{
1,2Department of Pediatrics, AJ Institute of Medical Sciences, Mangaluru, Karnataka, India
}

Corresponding Author: Santosh T Soans, Department of Pediatrics, AJ Institute of Medical Sciences, Mangaluru, Karnataka, India, Phone: +91 9343565558, e-mail: drsoans62@gmail.com

How to cite this article: Soans ST, Panambur S. Sepsis Mimics. Pediatr Inf Dis 2019;1(4):145-147.

Source of support: Nil

Conflict of interest: None

\section{Inborn Errors of Metabolism}

Inborn errors of metabolism (IEM) are a group of inherited disorders with varied clinical presentations such as poor feeding, vomiting, and lethargy that mimic sepsis and make the diagnosis a real challenge. Suspect IEM when there is normal birth event followed by deterioration after a period of normalcy, history of consanguineous marriage, abortions, intrauterine death, previous unexplained sibling death, and abnormal odor in breath or urine. The presence of ketonuria in the absence of hyperglycemia and persistence of high lactate levels despite hemodynamic and microperfusion correction is highly suggestive of underlying IEM. Diagnosis can be confirmed by genetic or enzyme assays. Bicarbonate therapy which is not used in acidosis related to sepsis may need to be used in IEM along with other therapeutic strategies.

\section{Macrophage Activation Syndrome}

Macrophage activation syndrome (MAS) is a life-threatening complication of rheumatic diseases which can be triggered by sepsis, or its presentation can mimic sepsis. Rapid worsening of clinical course, change in fever pattern, development of new organ dysfunction, or sterile cultures with poor response to antibiotics should raise suspicion for MAS. Moreover, patients may show a paradoxical improvement in the underlying inflammatory disease at the onset of MAS with the presence of relative thrombocytopenia, low erythrocyte sedimentation rate (ESR) with raised C-reactive

() The Author(s). 2019 Open Access This article is distributed under the terms of the Creative Commons Attribution 4.0 International License (https://creativecommons. org/licenses/by-nc/4.0/), which permits unrestricted use, distribution, and non-commercial reproduction in any medium, provided you give appropriate credit to the original author(s) and the source, provide a link to the Creative Commons license, and indicate if changes were made. The Creative Commons Public Domain Dedication waiver (http://creativecommons.org/publicdomain/zero/1.0/) applies to the data made available in this article, unless otherwise stated. 


\begin{tabular}{|c|c|c|}
\hline $\begin{array}{l}\text { Clinical condi- } \\
\text { tion }\end{array}$ & Diagnostic clues & Treatment \\
\hline \multirow[t]{2}{*}{ DKA } & $\begin{array}{l}\text { Ketosis, acidosis, } \\
\text { and hyperglycemia }\end{array}$ & - Insulin drip \\
\hline & & - Fluid resuscitation \\
\hline \multirow[t]{2}{*}{ KD } & $\begin{array}{l}\text { - Atypical } \\
\text { presentation }\end{array}$ & $\begin{array}{l}\text { - Intravenous } \\
\text { immunoglobulin is } \\
\text { standard of care }\end{array}$ \\
\hline & $\begin{array}{l}\text { Persistent fever } \\
\text { more than } 5 \text { days }\end{array}$ & \\
\hline IEM & $\begin{array}{l}\text { Consanguinity, } \\
\text { sibling death, and } \\
\text { developmental } \\
\text { delay }\end{array}$ & $\begin{array}{l}\text { Bicarbonate } \\
\text { therapy may be } \\
\text { needed }\end{array}$ \\
\hline \multirow[t]{2}{*}{ MAS } & - Rapid worsening & $\begin{array}{l}\text { Steroids are } \\
\text { the mainstay of } \\
\text { treatment }\end{array}$ \\
\hline & - Low ESR, high CRP & \\
\hline \multirow[t]{2}{*}{ Anaphylaxis } & $\begin{array}{l}\text { Acute onset, } \\
\text { allergen exposure }\end{array}$ & $\begin{array}{l}\text { 1:1,000 IM } \\
\text { epinephrine } \\
\text { (maximum three } \\
\text { doses) }\end{array}$ \\
\hline & $\begin{array}{l}\text { - Two or more organ } \\
\text { systems }\end{array}$ & \\
\hline $\begin{array}{l}\text { Adrenal } \\
\text { insufficiency }\end{array}$ & $\begin{array}{l}\text { Hypotensive shock } \\
\text { refractory to fluids } \\
\text { and vasopressors }\end{array}$ & $\begin{array}{l}\text { IV hydrocortisone } \\
\text { (stress dose) or IV } \\
\text { dexamethasone } \\
4 \mathrm{mg}\end{array}$ \\
\hline
\end{tabular}

DKA, diabetic ketoacidosis; KD, Kawasaki disease; IEM, inborn errors of metabolism; MAS, macrophage activation syndrome

protein (CRP), high triglycerides, and low fibrinogen levels. Steroids are the mainstay of treatment, and most patients respond briskly. However, it has high mortality if not identified early. Immunosuppressive agents and immunomodulators can also be tried.

\section{Anaphylaxis}

Recognition of anaphylaxis may be straightforward when symptoms are preceded by exposure to known allergen. However, the diagnosis can be challenging in the absence of allergen exposure. In such scenarios, anaphylaxis is highly likely in an acute onset hemodynamic instability involving at least two organ systems such as the dermal, gastrointestinal, respiratory, or hemodynamic system. Fever is unlikely to be present and patient may present in distributive shock. First and most important therapy in anaphylaxis is epinephrine. Administer 1:1000 epinephrine 0.15-0.5 mL intramuscularly (IM). If initial IM epinephrine is insufficient, provide another IM dose (maximum three doses) and thereafter start intravenous (IV) epinephrine infusion at $0.1-1 \mu \mathrm{g} / \mathrm{kg} /$ minute, titrated to effect. Consider IV corticosteroids and antihistamines prior to starting epinephrine infusion. ${ }^{3}$

\section{Adrenal Insufficiency}

This occurs in children with chronic adrenal failure under severe physiologic stress. Adrenal crisis is a great imitator. Children often present with a constellation of nonspecific signs and symptoms including fever, nausea, vomiting, abdominal pain, lethargy,
Table 2: Characteristics of sepsis and pseudosepsis

\begin{tabular}{|c|c|c|}
\hline Parameters & Sepsis & Pseudosepsis \\
\hline Clinical & $\begin{array}{ll}\text { - } & \text { Hyperthermia/ } \\
\text { hypothermia } \\
\text { - Tachycardia + } \\
\text { - Hypotension }\end{array}$ & $\begin{array}{ll}\text { - } & \text { Hyperthermia/ } \\
\text { hypothermia } \\
\text { - Tachycardia + } \\
\text { - Hypotension }\end{array}$ \\
\hline Hemodynamic & $\begin{array}{l}\text { - } \quad \downarrow \text { Peripheral vascular } \\
\text { resistance } \\
\text { - } \quad \uparrow \text { Cardiac output }\end{array}$ & $\begin{array}{ll}\text { - } & \downarrow \text { Peripheral } \\
& \text { vascular resistance } \\
\text { - } & \uparrow \text { Cardiac output }\end{array}$ \\
\hline \multirow[t]{6}{*}{ Laboratory } & $\begin{array}{l}\text { Leukocytosis/ } \\
\text { leukopenia }\end{array}$ & - Leukocytosis \\
\hline & - Thrombocytopenia & $\begin{array}{l}\text { - Normal/elevated } \\
\text { platelet counts }\end{array}$ \\
\hline & - $\uparrow$ Lactate & - $\uparrow$ Lactate \\
\hline & - $\downarrow$ Albumin & - $\downarrow$ Albumin \\
\hline & $\begin{array}{l}\text { Deranged } \\
\text { coagulation profile }\end{array}$ & $\begin{array}{l}\text { Deranged } \\
\text { coagulation } \\
\text { profile }\end{array}$ \\
\hline & $\begin{array}{ll}\text { - } & \text { Elevated } \\
\text { procalcitonin levels }\end{array}$ & $\begin{array}{l}\text { - } \text { Normal } \\
\text { procalcitonin } \\
\text { levels }\end{array}$ \\
\hline \multirow[t]{2}{*}{ Microbiologic } & $\begin{array}{l}\text { - Definite source of } \\
\text { infection }\end{array}$ & $\begin{array}{l}\text { - No definite source } \\
\text { of infection }\end{array}$ \\
\hline & $\begin{array}{l}\text { - Positive blood } \\
\text { culture }\end{array}$ & $\begin{array}{l}\text { Negative } \\
\text { blood cultures } \\
\text { (excluding } \\
\text { contaminants) }\end{array}$ \\
\hline
\end{tabular}

malaise, and altered sensorium. Laboratory findings often include hyponatremia, hyperkalemia, hypoglycemia, and hypercalcemia. The hallmark of adrenal crisis is hypotensive shock refractory to fluid resuscitation and vasopressors. Evaluate carefully for risk factors like corticosteroid use over 2 weeks, cancer, or tuberculosis in such circumstances. Baseline cortisol can be tested to confirm the diagnosis. Stress dose IV hydrocortisone or IV dexamethasone $4 \mathrm{mg}$ is lifesaving along with D5 normal saline for repletion of glucose. $^{2}$

Diabetic ketoacidosis, KD shock syndrome, systemic vasculitis, pancreatitis, aspiration pneumonia, and IEM mimic the clinical presentation of sepsis, whereas conditions such as anaphylaxis, adrenal insufficiency, hemorrhage, pulmonary embolism, and spinal cord injury mimic the hemodynamic parameters of sepsis. ${ }^{4,5}$

\section{Management}

Due to a significant overlap in the clinical, hemodynamic, as well as laboratory parameters, sepsis and its mimics are often not distinguishable on the initial assessment (Table 2). Using a systematic approach will provide the best avenue for diagnosis and treatment.

\section{Evaluation}

A focused history and detailed examination from head to toe is essential to evaluate for the source of sepsis.

- Search for a potential source of sepsis using the mnemonic LUCCAASS: lung (pneumonia), urine (cystitis/pyelonephritis), cardiac (endocarditis), central nervous system (meningitis, 
encephalitis), abdominal (abscess, cholecystitis), arthritis (septic arthritis), spine (osteomyelitis, abscess), and skin (cellulitis, IV line/peripherally inserted central catheter infection).

- Send appropriate laboratory studies which include a complete blood count, basic metabolic panel, urine analysis, chest radiograph, blood cultures, lactate, and none specific for sepsis.

- Procalcitonin has shown some promise in diagnosing bacterial sepsis.

- If no source of infection is identified, evaluate further for conditions that can mimic sepsis. ${ }^{6,7}$

\section{Treatment}

Irrespective of the underlying condition, the primary goal is to resuscitate and stabilize.

- Standard approach of airway, breathing, circulation, disability, exposure is followed.

- Obtain IV access and initiate fluid bolus to improve perfusion and preload.

- Start on broad spectrum IV antibiotics.

Frequent evaluation of the patient for response to treatment is necessary, and any worsening of clinical course despite adequate measures should raise the suspicion of alternate diagnosis. Once an etiology has been identified, treatment and further management is tailored according to the underlying condition. Timely intervention and prompt therapy of sepsis mimics is important as many can be progressive and fatal. ${ }^{8}$

\section{SUMMARY}

Approach a patient with sepsis or its mimic in a similar modality according to that the resuscitation takes precedence, followed by targeted history and examination. Consideration of sepsis vs its mimics can be completed while resuscitation is underway. Do not anchor on sepsis if no source of infection is found. Systematic approach and frequent evaluation is necessary to identify a sepsis mimic. Once an etiology is discovered, treatment and management can be targeted. Nonetheless, sepsis is still the commonest, mimics are there but rare!!

\section{References}

1. Long B, Koyfman A. Clinical mimics: an emergency medicine focused review of sepsis mimics. J Emerg Med 2017;52(1):34-42. DOI: 10.1016/j.jemermed.2016.07.102.

2. Lagi A, Cencetti S. Clinical sepsis mimic. J Gen Med Prim Care 2017;1(1):100004.

3. Boushra MN, Miller SN, Koyfman A, et al. Consideration of occult infection and sepsis mimics in the sick patient without an apparent infectious source. J Emerg Med 2019;56(1):36-45. DOI: 10.1016/ j.jemermed.2018.09.035.

4. Cunha BA. Sepsis and its mimics. Intern Med 1992;13:48-55.

5. Jones $A E$, Heffner $A C$, Horton JM, et al. Etiology of illness in patients with severe sepsis admitted to the hospital from the emergency department. Clin Infect Dis 2010;50(6):814-820. DOI: 10.1086/650580.

6. Cunha BA. Sepsis and its mimics in the critical care unit. Infectious Diseases in Critical Care Medicine 2007;2:73-78.

7. Cunha BA, Shea KW. Fever in the intensive care unit. Infect Dis Clin North Am 1996;10(1):185-209. DOI: 10.1016/S0891-5520(05)70294-4.

8. Rhodes A, Evans LE, Alhazzani W, et al. Surviving sepsis campaign: international guidelines for management of sepsis and septic shock: 2016. Intensive Care Med 2017;43(3):304-377. DOI: 10.1007/s00134017-4683-6. 